\title{
Kismet: Hollywood, Orientalism and the Design Language of Padraic Colum's Mogu of the Desert
}

\author{
Elaine Sisson
}

When the Gate Theatre staged Padraic Colum's Mogu of the Desert in 1931, the play had been in circulation since 1908. The Gate's production was its first staging, although it was not a success and closed after two performances. The content and form of the play differs greatly from Colum's earlier works for the Abbey (especially Thomas Muskerry, 1910, and The Land, 1905) and is described in the Irish Press as 'a fantastical comedy [...] on Persian themes' (28 December 1931). This in itself is something of a misnomer, since it is neither fantastical nor comedic. Colum had reworked Mogu numerous times since its first publication as part of his ongoing exploration of transcultural narratives. By the time of the Gate production Colum had already published a series of Hawaiian folk tales, in addition to books on Norse, Greek, Irish and Celtic mythology. ${ }^{1}$

E. Sisson $(\varangle)$

Institute of Art, Design and Technology, Dublin, Ireland e-mail: Elaine.Sisson@iadt.ie

(C) The Author(s) 2021

O. Pilný et al. (eds.), Cultural Convergence, https://doi.org/10.1007/978-3-030-57562-5_7 
An analysis of Mogu's design and staging - and, in particular, its costume and set design - in relation to its Middle Eastern subject matter reveals how this production was part of a broader engagement with 'exotic' or oriental narratives at the Gate that were influenced by popular cinema, in particular the film versions of Edward Knoblock's play Kismet. This chapter looks at the history and subject matter of Colum's play Mogu, as context in which to discuss Mac Liammóir's fascination with oriental and Middle Eastern culture within film and popular culture. Further, the documentary traces of Mogu, left behind in costume designs, set drawings and production photographs, provide an understanding of theatre as a commercial enterprise.

Although written in 1908, by 1912 there was a certain amount of controversy brewing around Colum's play. Colum maintained the West End hit musical Kismet, packing houses in London's Garrick Theatre, was in fact based on Mogu The Wanderer or The Desert. We know this because two letters to the Irish Times appeared on the same day, 5 April 1912 (one from Colum, and the other from Tom Kettle), drawing attention to the similarities between Kismet and Colum's play, referred to in the correspondence as 'The Desert'. Colum was vexed at what he considered to be outright plagiarism. As Kettle says in his letter, 'Mr. Colum had spoken constantly to me about "The Desert" from 1907; in the spring of 1908 he showed me the first draft, afterwards re-written; and in the winter of 1908 I saw the final version.' Furthermore, says Kettle, 'I happen to know that from this date on the MS [manuscript] was going the rounds of various London theatres.' (Kettle) Colum's letter was slightly more conciliatory, acknowledging that the plays represented what we would now call Zeitgeist, but what he describes as 'correspondences' of 'certain psychic phenomena'. Nevertheless, his letter revealed he had organized a reprinting of his play, asking a committee of 'disinterested' 'gentlemen' to ascertain whether or not there were any similarities with 'Kismet' (Colum). The members of the committee were no lightweights: W.B. Yeats, George Russell, Edward Martyn, Lord Dunsany, Tom Kettle, Professor Donovan and the editors of both the Irish Times and The Freeman's Journal were asked to read both plays. Kettle's letter calls the similarities 'the strangest coincidence in literature that I have ever encountered' (Kettle). Ernest Boyd noted that it shared an interest in 'the romance of that vague Orient' that characterized the dramatic work of Lord Dunsany (118). 
Edward Knoblock had allegedly written Kismet in 1911 and it was first performed at the Garrick Theatre in London, running for over two seasons. Knoblock had been commissioned to write the play for the leading theatrical manager, producer and actor Oscar Asche, who may or may not have seen a script of Colum's play when it was doing the rounds of London theatres some years previously. ${ }^{2}$ While Knoblock's play was still running in London, another production of Kismet opened in New York and Asche also produced a successful run of the play in Australia. The commercial success of Kismet makes it easy to understand how galling this was for Colum. Perhaps it was the prospect of Knoblock's show coming to Dublin that precipitated the republishing of Mogu the Wanderer, or the Desert in 1912 in order to support Colum's charge of plagiarism. By April 1912, the Irish Times was reporting that 'everyone who went to London $[\ldots]$ tried to see "Kismet" at the Garrick. The world and his wife were going to it, and it was eminently the thing'. However, the paper went on, disappointed Irish theatre-goers were now being treated to the West-End production at the Theatre Royal in Dublin. The Irish Times reviewer praised the 'Arabian nights entertainment' and 'the glamour of the Orient' featuring 'girl slaves and eunuchs', as well as dancing and magicians ("'Kismet" at the Theatre Royal').

Nevertheless, almost twenty years had passed by the time of the Gate's production of Mogu in 1931. On the face of things, it seems a peculiar choice for Edwards and mac Liammóir to make: the play is not very modern, nor does it offer opportunities for avant-garde experiments. After all, this was to be only the third season in the Gate's new home at the Rotunda, and the theatre was slowly building up its reputation for edgy, experimental drama. Mac Liammóir's interest in Mogu may be attributed to two things: first, a genuine desire to support Padraic Colum in admiration of his work, and second, the potential to stage a homegrown version of Kismet which had enjoyed sustained popular attention in two film versions.

Although Kismet was a theatrical success in the 1912-1914 London season, its broader legacy may be traced largely through cinema. Kismet was filmed in 1920, 1930, 1944 and 1955 but today's audiences are probably most familiar with the Hollywood musical versions dating from the 1940s and 1950s. ${ }^{3}$ It is the 1920 and 1930 film versions of Kismet that are of interest here. The silent film version of 1920 starred Otis Skinner and Elinor Fair and was directed by Louis J. Gasnier. It was filmed again as a talkie in 1930, directed by John Francis Dillon for Warner Bros and 
again featuring Otis Skinner, this time appearing opposite Loretta Young. The 1930 film is now lost but its pre-Hay's code aesthetic, particularly of the harem scenes, attracted interest. ${ }^{4}$ Dublin cinema listings for 1931 show that there was a screening of the 1930 talkie Kismet at the Theatre Royal on 21 July 1931, some five months before Mac Liammóir staged Mogu. The film was advertised in the Irish Times under the tagline as 'a dramatic story of Eastern fatalism. A beggar's rise from rags to riches. Love and Hate. Desire and Revenge' (21 July 1931). An article in the same paper highlighted the upcoming visit to Dublin of the film, noting that it had 'peculiar interest for Dublin because of its theme's similarity to that of a play by one of the most prominent Abbey Theatre authors' (20 July 1931). The publicity for, and success of, the film may better explain why Colum's Mogu made it to the Gate stage in time for the Christmas 1931 season.

Mac Liammóir was an admirer of Colum and recalls conversations with the playwright 'about his play and of his hopes that [the Gate] would put it on' (144). In All for Hecuba, he concedes that the story of Mogu, as relayed by Colum, with its magic Arabian carpets, flowers, jewels and 'impossible adventures' did not translate well to the stage. 'The story was involved', he writes, 'the characters shadowy, the imagery forced and derivative as in so many pseudo-Oriental plays.' (145) Nevertheless, the production design setting, 'a rainbow-coloured path through a maze of deserts and mosques and moonlight gardens' (144) proved hard to resist. Mac Liammóir loved the style of Persian miniatures, exemplified in the work of Mirza Ali, and whose influence can be seen in his design for Mogu (see Fig. 7.1). ${ }^{5}$ The flamboyance of the set and costume design did not convince the reviewer from the Irish Press of the merits of the play, who, rather cuttingly, described its plot as full of 'mysticism, contentions, jealousies and humour' with an 'underlying profundity' that 'best suits the histrionic abilities of the Gate Theatre Company' (28 December 1931).

Mogu of the Desert was neither a critical nor a commercial success and, accordingly, has prompted little interest from literary or theatre historians: it is not even listed in PLAYOGRAPHYIreland. It tells the story of the beggar Mogu whose extremely beautiful daughter, Narjis, catches the eye of the Persian King. After their marriage, Mogu's fortunes and status improve; however, his power makes him pompous and he attracts selfserving cronies. Years later, after the King dies, Mogu and his daughter lose their social position and by the end of the play they are penniless and reduced to wandering the desert once again. Hilton played Mogu, 'a 


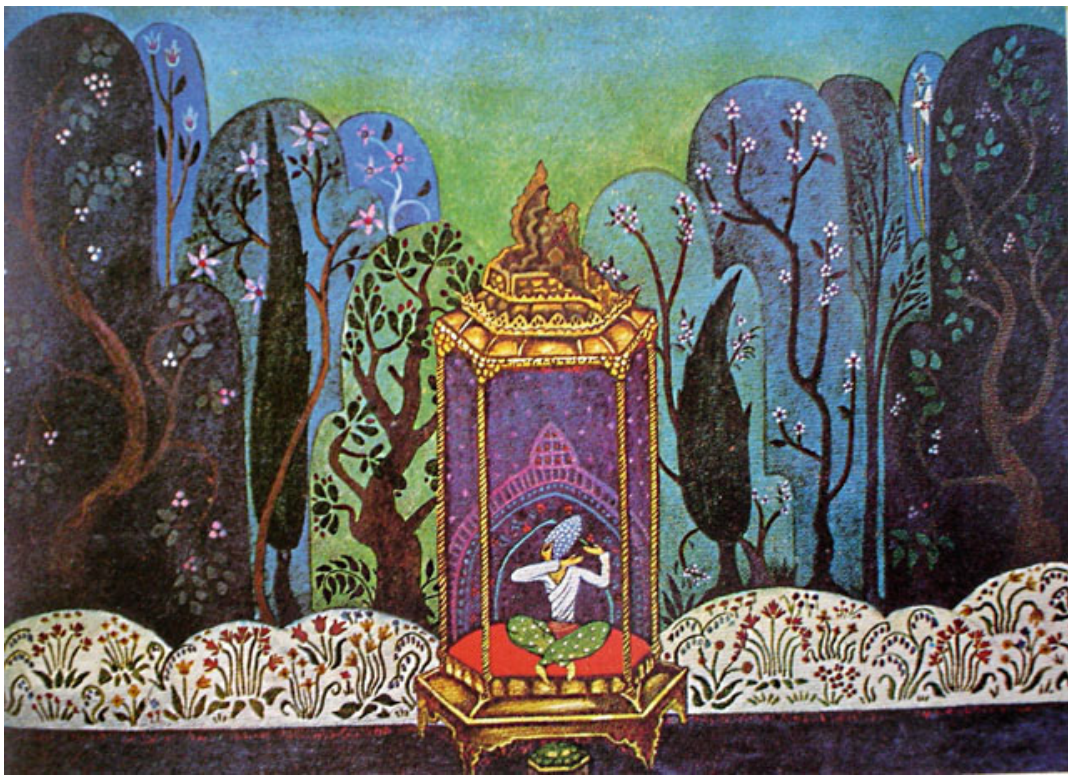

Fig. 7.1 Micheál mac Liammóir, set design for Padraic Colum, Mogu of the Desert, Gate Theatre, 1931. Gate Theatre Archive, Northwestern University (Copyright of the Edwards - mac Liammóir Estate)

grand bulging lecherous oily performance', with Betty Chancellor as his daughter (mac Liammóir 145). Orson Welles, the new kid in town, played Chrosoes, the King of Persia or the Grand Vizier, 'which involved several pounds of nose putty, a white turban at least two and half feet in diameter, and three-inch fingernails of peacock-blue and silver' (mac Liammóir 145). Design was by mac Liammóir, with incidental music composed by Frederick May.

Mac Liammóir was an admirer of Leon Bakst and of the oriental dances of the Ballet Russes, as is clear from his memoir All for Hecuba. ${ }^{6}$ Indeed, Katherine Hennessey has described mac Liammóir's work as a 'mélange of Celtic Twilight inspiration and cutting edge continental theatrical innovation' (66). However, by 1930, the oriental-style influences of the Ballet Russes were well established, even a little old-fashioned, given that its deepest influence was during the pre-war period, and in the 1930s the visual language of Ballet Russes was understood as belonging to a rather 
outdated art nouveau expression, rather than to the contemporary cutting edge styles of art deco and streamline moderne. Although the design language of stage and dance is important to mac Liammóir's aesthetic during this period, my argument here is that the visual language of the cinema is equally, if not as, significant. Undoubtedly, Mogu was staged partly out of loyalty to Colum, whose work had been 'gradually neglected' by the Abbey despite his early successes there, but by placing Mogu within the context of mass culture, a more hard-headed commercialism is discernible, acknowledging the appeal of popular cinema (Boyd 119).

While theatre historians acknowledge the influence of stage design on early cinema (such as fixed cameras, painted backdrops and acting styles), the production values of cinema (lighting effects and the use of shadows, for example) are often overlooked as features of stage design. ${ }^{7}$ Nonetheless, the design of Mogu is evidently influenced not only by the stage show of Kismet, but also by films with 'exotic' themes popular with cinema audiences. There are a few productions by the Gate in the 1920s and 1930s with oriental or 'exotic' themes which had first come to popular attention as films (featuring stars like Theda Bara and Rudolph Valentino) rather than the original plays. For example, the Gate's productions of Wilde's Salomé (1928), Goethe's Faust (1930) and Ibáñez's Blood and Sand (1933) were all preceded by film versions already seen in Dublin cinemas. ${ }^{8}$

In the case of Salomé, mac Liammóir had two recent film versions to draw on. J. Gordon Edwards's version, featuring Theda Bara, had been made in 1918 but only appeared on Irish screens after 1920. The more significant version, however, was Alla Nazimova's 1923 Salomé, with set and costumes designed by Natacha Rambova. Nazimova's film was seen across Irish cinemas during 1924-1925 in Belfast, Derry, Dublin, Clonmel, Tralee and Omagh. Visually, the impact of both Aubrey Beardsley's 1893-1894 illustrations and, in turn, his influence on Rambova's designs for Salomé (1923), is visible in mac Liammóir's designs for the Gate's 1928 staging of the play. Mac Liammóir's costume designs, especially his design for Herod, attest to this influence. ${ }^{9}$ Similarly, the influence of F.W. Murnau's 1926 film Faust is clearly evident in production photographs of the Gate's February 1930 production of Faust where the design of the costume and makeup of the central character are closely modelled on that of Murnau's film. ${ }^{10}$

In addition, the popularity of the 'sheik' film in the 1920s and 1930s has been linked to the emergence of the 'desert romance' novel genre 
during this period. Hsu-Ming Teo observes that the release of the 1921 film, The Sheik, starring Rudolph Valentino, marked a high point in the 'sheik fever' generated by popular romance novels which created 'new connotations of irresistible, ruthless, masterful, and over-sexualised masculinity' (12). ${ }^{11}$ Valentino, the premier matinée idol of the 1920s, appeared in the blockbusters The Sheik (1921) and The Son of the Sheik (1926). Representations of the 'exotic Orient' included the erotic manifestation of the East: harems of beautiful women and belly-dancers. As Teo remarks, 'scenes of belly dancers in gauzy, spangled dress' dominated Hollywood films about the Orient from the early twentieth century (117).

What the context of cinema offers is modernity - the sense of being 'of the moment' appearing alongside popular discourses of orientalism (in novels and fashion) which foreground the body. It is important to understand that orientalism is not geographically specific - here it is a conjuring of 'otherness' that expands to include Palestine, Spain or Persia. As Teo notes, the 'locus sensualis' of the 'East', constructed and mythologized in 'a centuries-long literary engagement between Europe and the Muslim world', may be vaguely geographically located within 'the Islamic Middle East and North Africa - from Morocco to present-day Iran' (6).

Holly Edwards argues that although orientalism influenced the growth of consumer culture through the design and display of 'exotic' goods, and more importantly, through its dissemination as popular culture, it offered a narrative of bohemian sexuality to bourgeois audiences (11-57). ${ }^{12}$ This fascination can certainly be seen in Ireland, where there was a vogue for young middle-class women to dress as 'gypsies', 'oriental girls' and bacchantes in fancy dress balls and charity events throughout the 1920s. Photographs taken at the National Children's Hospital fête in the Iveagh Gardens, Dublin in 1920 for example (see Fig. 7.2) show young women smoking cigarettes in the 'Chu Chin Chow Gardens' while dressed in 'oriental' and 'gypsy' outfits as part of the fundraising activities. ${ }^{13}$

The female volunteers signal their bohemianism by dressing in 'gypsy' costumes that are vaguely generalized: headscarves, hooped earrings and patterned loose clothing as well as the 'oriental' costume of harem pants, headdresses and loose jewellery. That all of the women featured are smoking indicates the conjunction between orientalist fashion and modernity. The appropriation of 'exotic' clothing in the context of costume enabled young women to display a scandalous modernity simultaneously disavowed by the fact that they were in 'fancy dress'. Donatella Barbieri notes how the visual language of Middle Eastern orientalism within 


\section{Some Happy Snap-Shots at the May Fête}

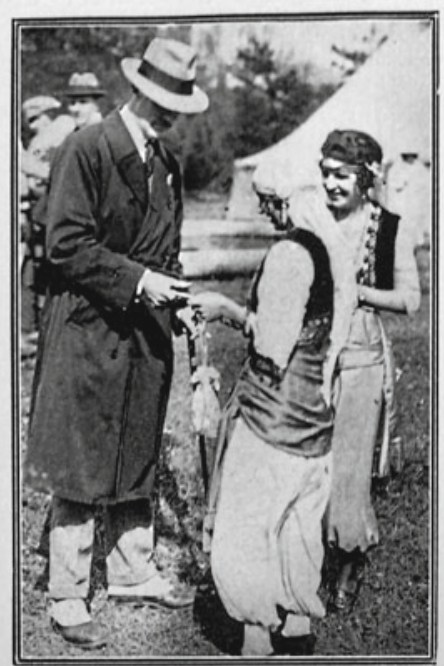

Lord Powerscourt buys " Just one more" ticket for a raflle,

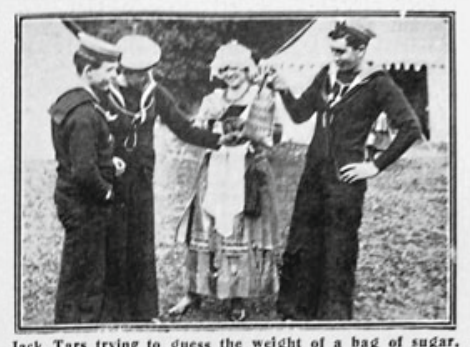

Jack Tars trying to guess the weight of a bag of sugar, "at a price!"

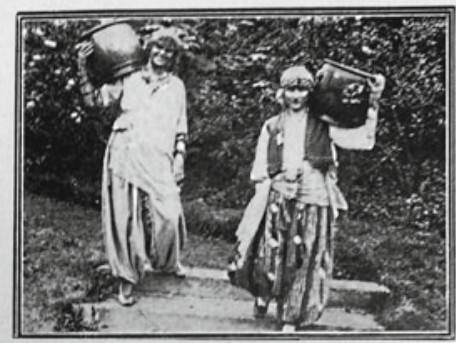

I Vision of the East at the Féte.

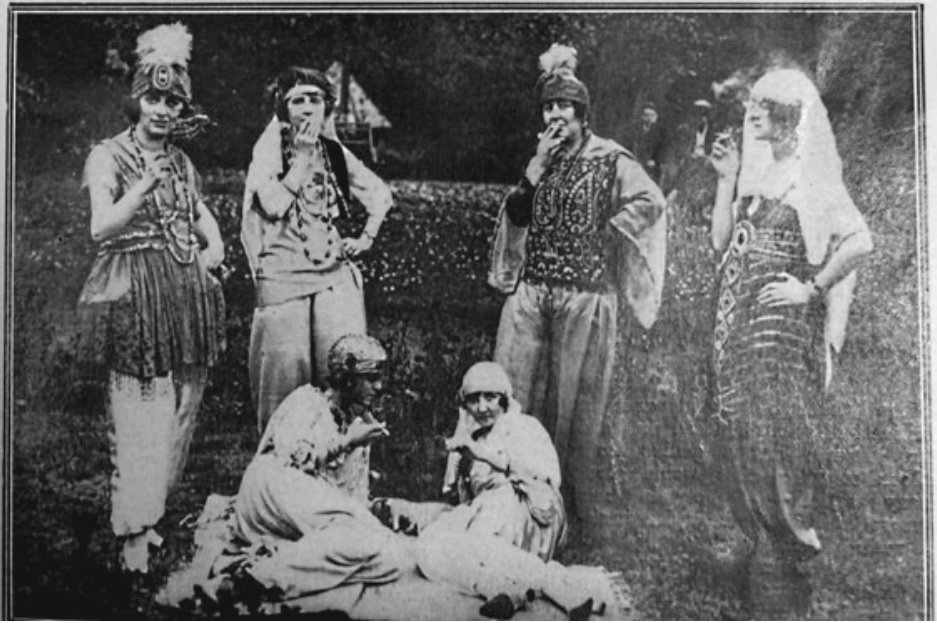

Fig. 7.2 Oriental costume on display at the National Children Hospital's Fundraiser, Iveagh Gardens, Dublin. Irish Life, 21 May 1920 
popular culture is 'one of European white bodies, luxuriously dressed in a mixture of invented Eastern costumes of diaphanous veils' (104). 'Oriental' fancy dress allowed white women to perform a sexually liberating identity and, as Susan Nance says, to use 'the persona of the mischievous Eastern Dancer' as a 'vehicle for colloquially feminist, sexually self-aware consumer individuation' (17).

Orientalist narratives require the display of the body through the eroticization of costume - legitimizing the costumed body as a to-belooked-at space. Whether on stage, screen or a garden fête, the orientalist, bohemian or 'other' spaces being invoked are done so most effectively through location and physical display. Arguably then, the Gate's oriental settings may be read as expressing playfulness with 'transgressive' sexualities. The costumed 'exotic' body enables a freedom of sexuality that is permitted 'elsewhere'. Mac Liammóir's descriptions of his 1928 production of Salomé, for example, draw attention to its visual and sensual appeal: 'a lovely set in black and silver and viperish green with the entire cast stripped almost naked' (71). Mac Liammóir's costume drawings for $M o g u$ display male and female bodies both wrapped in diaphanous, luxurious fabrics. The decadent extravagance of costume is a premonition of what we now call 'camp' (see Figs. 7.3 and 7.4). Bob Hennessey's costume combines an electric blue sleeveless undershirt, with a leather harness and green and gold chiffon trousers.

Mac Liammóir's costume designs for Mogu showcase the erotic display of male and female bodies, to be scrutinized in the dark theatre, in much the same way as cinema enables private looking. Costume is distinguishable from 'dress' or fashion, in its differences in construction and use as well as its contexts and meanings. Mary Ellen Roach-Higgins and Joanne B. Eicher distinguish between clothing that functions as 'modifications of the body and/or supplements to the body' and costume which 'indicate[s] the 'out-of-everyday' social role or activity' (1995, $7)$. Eicher has further argued that while dress establishes identity in everyday life', costume expresses 'a performance identity' $(2010,152)$. As Pravina Shukla has surmised, costume 'is usually set apart from dress in its rarity, cost, and elaborate materials, trims and embellishments, and in its pronounced silhouette or exaggerated proportions'. Where the object of costume is 'heightened communication' and 'spectacle for public consumption' she argues, it is the avoidance of the 'ordinary and its embrace of the "evocative" that is at the heart of the very set of meanings it is striving towards' (4). 


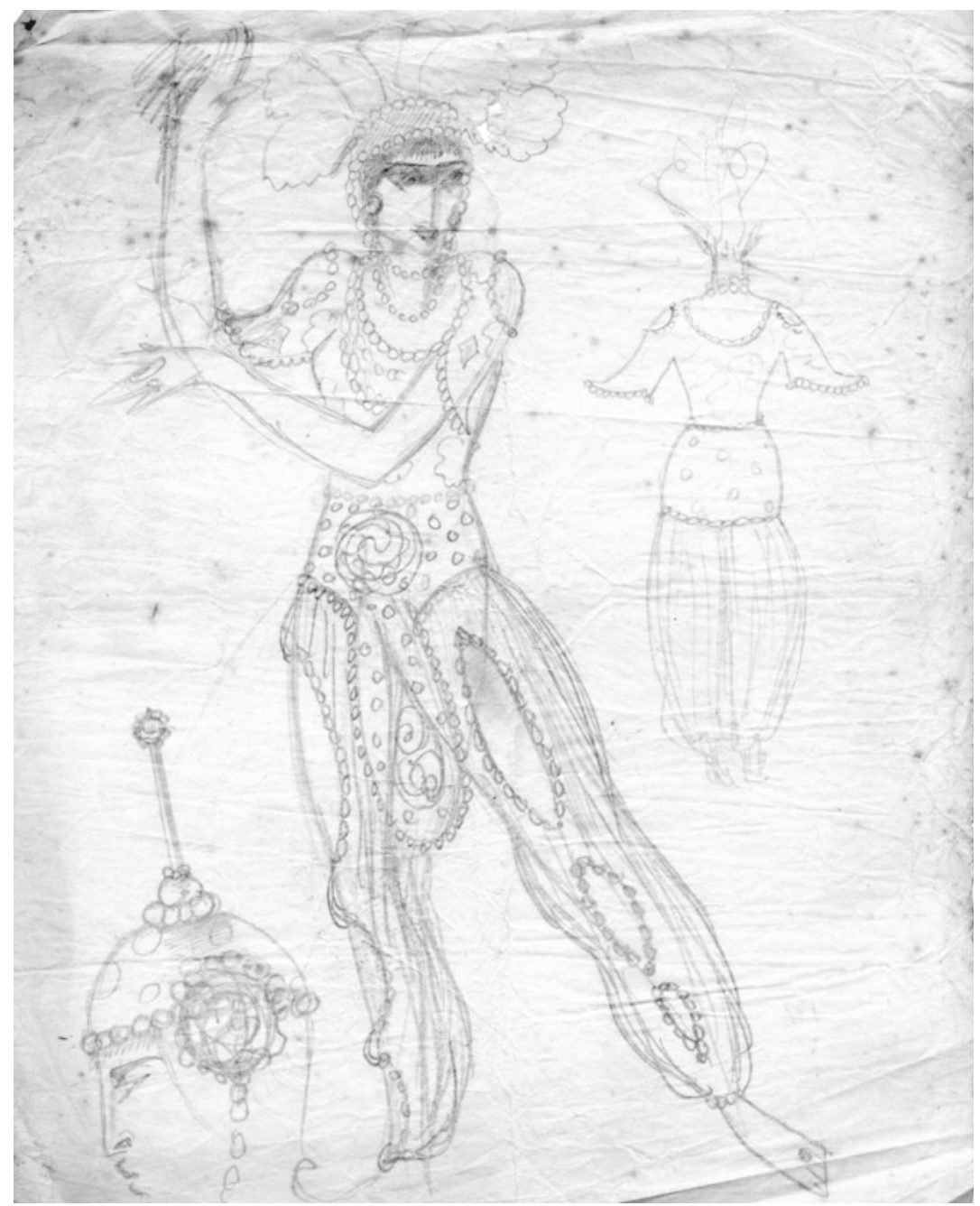

Fig. 7.3 Micheál mac Liammóir, costume design for female character, Mogu of the Desert, Gate Theatre, 1931. Gate Theatre Archive, Northwestern University (Copyright of the Edwards - mac Liammóir Estate) 


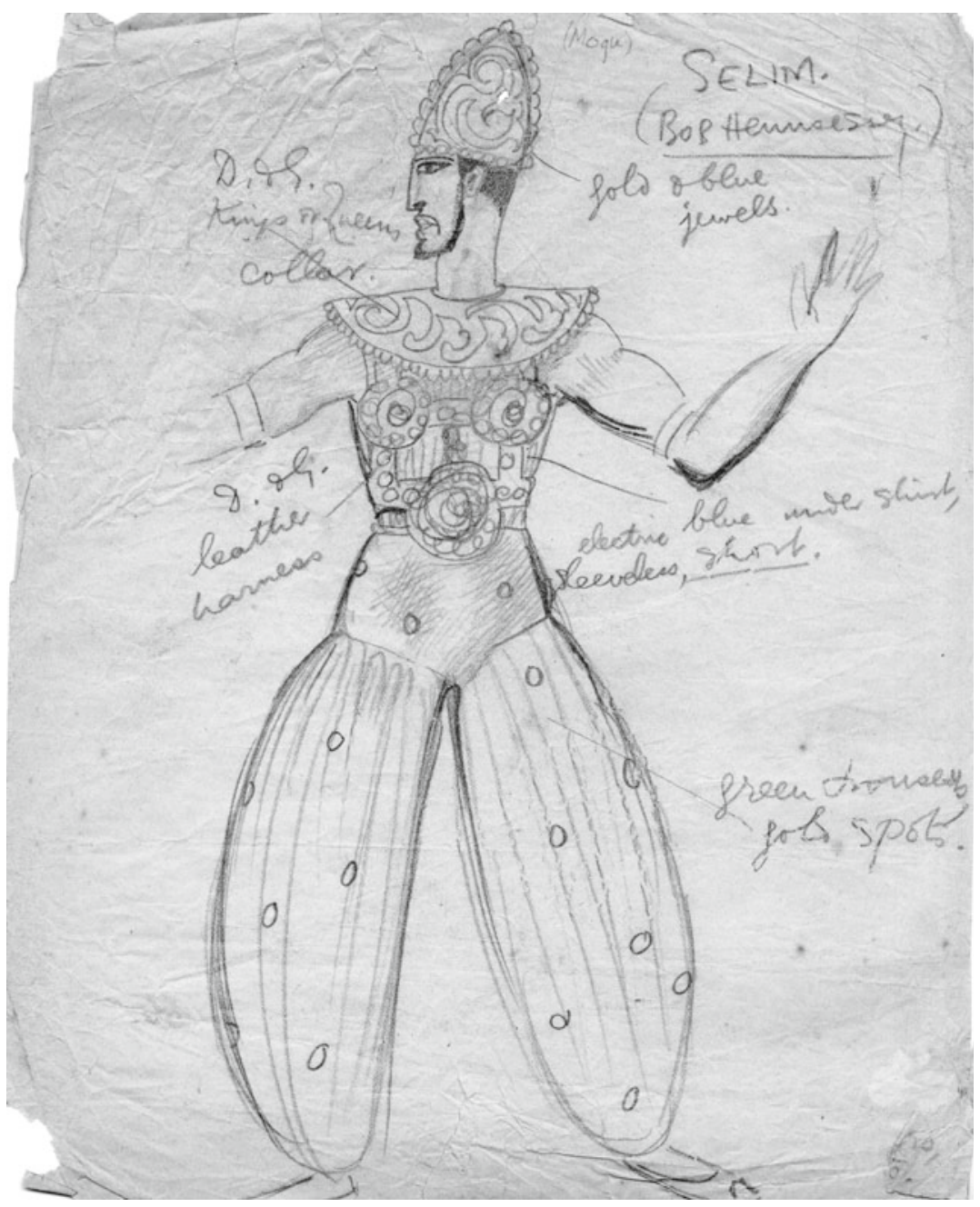

Fig. 7.4 Micheál mac Liammóir, costume design for 'Selim' (played by Robert Hennessey), Mogu of the Desert, Gate Theatre, 1931. Gate Theatre Archive, Northwestern University (Copyright of the Edwards - mac Liammóir Estate) 


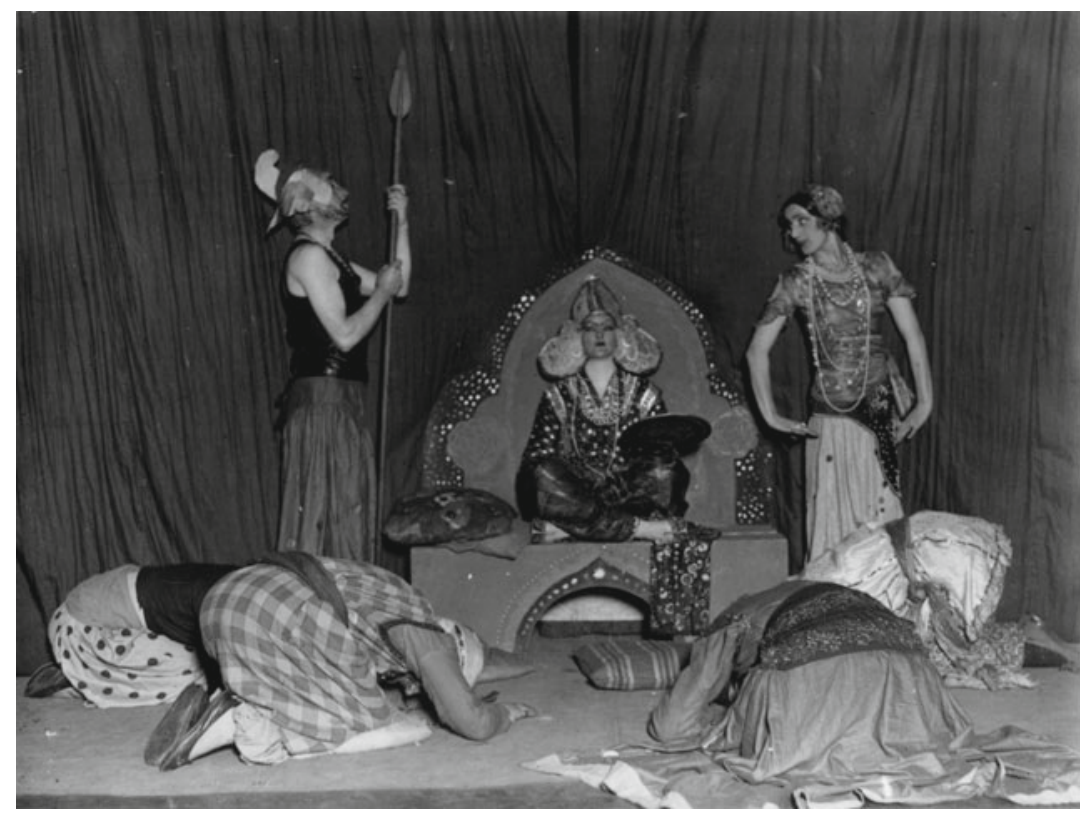

Fig. 7.5 Padraic Colum, Mogu of the Desert, Gate Theatre, 1931. Set and costume design by Micheál mac Liammóir. Gate Theatre Archive, Northwestern University (Copyright of the Edwards - mac Liammóir Estate)

Yet in theatre practice, there remains a gap between what might be called 'the poetic intention' of a design and its realization. Here we must acknowledge the difference between a drawing and a photograph, a model box and a finished set, a costume design and what an actor actually wears. The photograph at Fig. 7.3 shows the actual set of Mogu in contrast to mac Liammóir's set drawing at Fig. 7.1. Here artistic ambition is curbed by the constraints of the stage and by scale. Lack of money and financial necessity demands the use of cheaper materials to reproduce the highly ornate vision of the Persian miniature. Nevertheless, the desire for artistic experiment is present, and so, far from diminishing the original designs, the production photographs crystallize the real-world tension between ambition and realization: between theory and practice (Fig. 7.5).

Costume drawings may provide us with knowledge that photographs cannot about the process of theatre-making. Sketches and drawings are 


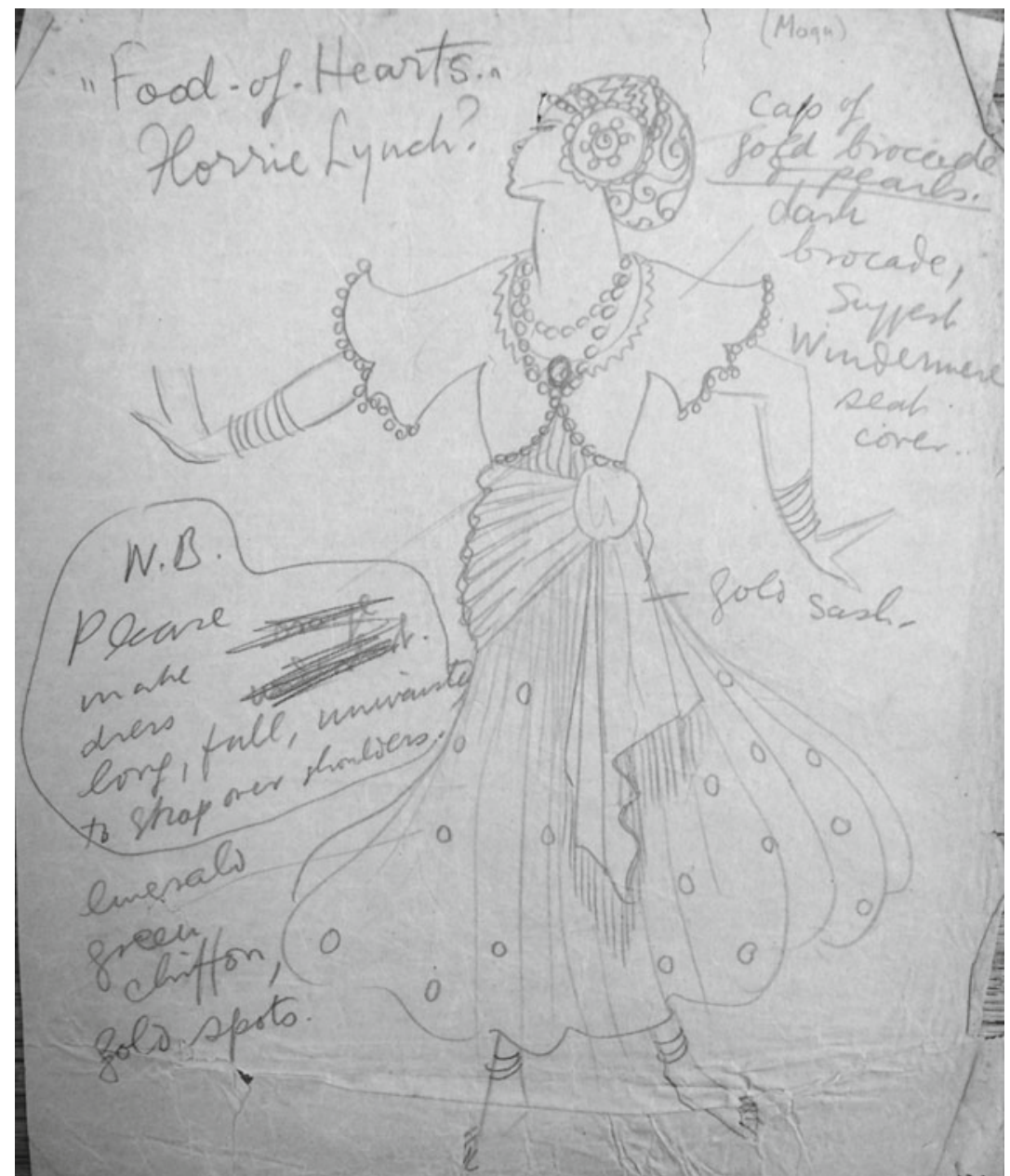

Fig. 7.6 Micheál mac Liammóir, costume drawing for 'Food-of-Hearts', Mogu of the Desert, Gate Theatre, 1931. Gate Theatre Archive, Northwestern University (Copyright of the Edwards - mac Liammóir Estate)

often overlooked as important sources of information in favour of more finished drawings, models or images. For example, mac Liammóir's rough instructional sketch for his dressmaker, Christine Keeley, at Fig. 7.6 tells 
us that the actress Florrie Lynch was being considered for the part of the slave girl 'Food-of-Hearts' (she was offered, and accepted, the part). In the absence of colour photography, or the costume itself, it also provides a key to the materiality, texture and colour scheme of the costumes. Foodof-Hearts's costume is of a diaphanous emerald green chiffon with gold spots, a gold sash and a gold-coloured cap made of brocade and pearls. Understanding the fabrics (even if they may have not been of the best quality) and colours enables us to see what the audience saw, how the costume moved on the body, how it might have looked under lights, and even what it sounded like as the actress moved across the stage.

However, a closer look at the costume drawing may prompt us to think not only about the process of the design and making of the physical object: chiffon and brocade; gold and green with details for the dressmaker. The costume drawing reveals the economic system within which theatre works: the dressmaker repurposes the brocade seat covers from an earlier production of Lady Windermere's Fan. Other drawings in the archive give instructions to recycle the curtains from the production of Mary Manning's Youth's the Season for Cecil Monson's Persian character.

Shukla categorizes costume creation into four types: those that can be 'pulled' (taken from existing stock), rented, bought, or 'built' (211). 'Building' a costume includes making an original item from a pattern but also adjusting or modifying existing costumes to create something new. The practice of 'building' and 'pulling' costumes was clearly the system within which the Gate theatre operated and it explains why no costumes have survived from this period. However, while the artefacts themselves no longer exist, mac Liammóir's costume drawings and designs have become coveted artistic objects and many of them are now in private collections. The absence of the costume as a material artefact in the archives may also explain why, as Aoife Monks has written, 'costume, in one way or another, is frequently looked through, around or over in theatre scholarship' (9). As Donatella Barbieri has observed, 'both costume and fashion act through the body intending to influence behaviour and thoughts and to communicate. In costume this is organised [around] an ordering principle that evaporates at the end of a performance.' (xxiii) It is this 'evaporation', this 'mutability', says Barbieri, that may explain 'why there has been so little written about costume throughout its long history of performance' (xxii).

Costumes are not just clothes that actors wear: they are part of the signification system of theatre - part of the material trace of performance, 
as cultural markers, as economic as well as designed objects. This squares with costume designer Sandy Powell's maxim that making a period feel authentic is more important than making it accurate: that costume is not about replication but about communication (qtd in Nadoolman Landis 118). Costume often reflects contemporary fashion and conventions, and, as seen in Mogu, costume works as an intertext: it contains modes of meaning that are not just about ancient Persia but something else - something modern and sexy and fun. Aoife Monks's work asks us to consider context: What is the relationship between the costumes on stage and what the audience is wearing; and how might the audience have understood them in the context of what was taking place in the wider culture? Doing this situates Mogu within contemporary fashion, middle-class bohemian fantasies and Hollywood movies.

Perhaps Mogu's greatest achievement was in providing the backdrop for one of the Gate's legendary parties, described in some detail by Mac Liammóir in All for Hecuba (147-53). It is in this description that the eroticized world of the Orient and the late-night party scene of Dublin in the early 1930s collide in a gossipy, champagne-fuelled recollection of the evening's antics. Guests included theatre students, college professors, politicians, musicians, writers and actors, and a selection of the city's bright young things. Drinks were served in the auditorium and dancing was on the stage surrounded by the debris of 'miraculous carnations and lilac-coloured banks of rock' that had comprised the Mogu set. The stage electrician had rigged up coloured lights that changed frequently, bathing the dancers in 'cool moonlight' followed by 'fire and flame', and the party ended in a 'Bacchic frenzy' with the Polish ambassador singing the national anthem of Poland (151).

The material culture of Mogu's set and costume designs demonstrates how the ephemera of productions may offer added dimensions to our understanding of a play: to think not only about a play's language but its experiential dimension - what audiences saw (colours, lights, spaces), as well as what they heard (the rustle of chiffon, the live music score). It challenges us to think more expansively about how theatre operates in a wider cultural context - where audiences go to the cinema as well as the theatre, and perhaps bring systems of reference from one to the other. A closer analysis of the Gate's production of Mogu illustrates how cultural exchange or dialogue may operate between different popular forms: cinema and variety, literature and film magazines, fashion and costume, and this blurring, so evident in the Gate's theatre practices, 
is quintessentially modern - the overlap between low and high culture, the emergence of the celebrity, the technologies of modernity and the economic necessities of recycling costumes so that the Gate's theatrical productions contain references folded into each other.

\section{Notes}

1. Colum's Hawaiian tales in print at the time of the Gate's production of Mogu of the Desert were commissioned by the Hawaiian Legend and Folklore Commission and illustrated by Juliette Fraser; they are: At The Gateways of the Day (3 vols; New Haven, CN: Yale University Press, 1924) and The Bright Islands (New Haven, CN: Yale University Press, 1925).

2. Oscar Asche promoted a number of oriental themed musical productions after Kismet, including Mameena (1915), Cairo (1921) and the smash hit Chu Chin Chow which ran from 1916 to 1921 in London, and played in Dublin's Gaiety Theatre in August 1920. See Singleton.

3. The 1920, 1930 and 1944 film versions of Kismet are based on the original 1911 play by Edward Knoblock. The 1944 version featured Ronald Colman and Marlene Dietrich and was directed by William Dieterle for MGM. The 1955 hit film was based on the award-winning Broadway musical loosely adapted from Knoblock's play with musical score by Robert Wright and George Forrest. Kismet (1955) was directed by Vincente Minnelli, also for MGM, and starred Howard Keel and Ann Blyth in the leading roles.

4. The Hays Code (or the Motion Picture Production Code), in force by 1934, monitored and governed 'moral' standards in American filmmaking.

5. The painter Mirza Ali, or Abd al-Samad, was one of the founders of the Mughal miniature tradition in sixteenth-century Persia.

6. In All for Hecuba, mac Liammóir laments his progress on his designs for Mogu, saying they 'were nothing but half-hearted echoes from Mirza Ali filtering down through Bakst and Edmund Dulac' (136).

7. I have written elsewhere on the influence of German expressionism on Irish stage design during this period: see Sisson (39-55).

8. Theda Bara appeared as Salomé in 1918, directed by J. Gordon Edwards for the Fox Film Corporation. By 1923 Alla Nazimova's version of Salomé overtook Edwards's film in popularity. The 1908 novel Blood and Sand by Vicente Blasco Ibáñez was made into a film, also directed by Ibáñez in 1916. A Hollywood version, based on the stage adaptation by Thomas Cushing, was made in 1922, starring Rudolph Valentino and directed by Fred Niblo for Paramount Pictures. 
9. The costume design for Herod by Micheál mac Liammóir, 1928, is in the University of Bristol Theatre Collection. Ref. TC/D/C/81.

10. The 1926 film version of Goethe's Faust directed by F.W. Murnau does not have any cinema listings in Ireland in the late twenties, but the 'homage' to the design makes it clear that mac Liammóir and Edwards saw the film prior to 1930 .

11. The best-selling romance novels of E.M. Hull were adapted for cinema. Hull's 1919 book The Sheik was filmed in 1921, and her 1925 novel, The Sons of Sheik, was filmed in 1926. Both films starred Rudolph Valentino (Teo 2).

12. Bram Dijkstra's work also explores the fascination with oriental settings and the emergence of the female 'vamp' at the turn of the last century. See Dijkstra.

13. A description of the event can be found in an Irish Times article of 14 May 1920 ('The May Fete'). The musical Chu Chin Chow, devised and directed by Oscar Asche, ran in London's West End from 1916 to 1921 , making it one of the most popular West End shows at the time. The 'Chu Chin Chow' gardens would have been understood by a contemporary audience as a reference to exotic Eastern orientalism.

\section{Works Cited}

'An Arabian Night'. 1931. Irish Times, 20 July.

Barbieri, Donatella. 2017. Costume in Performance: Materiality, Culture and the Body. London: Bloomsbury.

Boyd, Ernest Augustus. 1917. The Contemporary Drama of Ireland. Boston: Little Brown.

Cinema advert. 1931. Irish Times, 21 July.

Colum, Padraic. 1912. 'Letter to the Editor'. Irish Times, 5 April.

Dijkstra, Bram. 1986. Idols of Perversity: Fantasies of Feminine Evil in Fin-deSiècle Culture. Oxford: Oxford University Press.

Edwards, Holly. 2000. 'A Million and One Nights: Orientalism in America 18701930'. In Noble Dreams, Wicked Pleasures: Orientalism in America, 18701930. Ed. Holly Edwards. Princeton: Princeton University Press.

Eicher, Joanne B. 2010. 'Clothing, Costume and Dress'. In The Berg Companion to Fashion. Ed. Valerie Steele. New York: Berg.

Hennessey, Katherine Anne. 2011. Memorable Barbarities and National Myths. United States: Proquest, UMI Dissertation Publishing.

Kettle, Tom. 1912. 'Letter to the Editor'. Irish Times, 5 April.

"“Kismet” at the Theatre Royal'. 1912. Irish Times, 8 April.

mac Liammóir, Micheál. 1946. All for Hecuba: An Irish Theatrical Autobiography. Dublin: Monument Press. 
Monks, Aoife. 2010. The Actor in Costume. London: Palgrave Macmillan.

Nadoolman Landis, Deborah, ed. 2012. Hollywood Costume. London: V\&A Publishing.

Nance, Susan. 2009. How the Arabian Nights Inspired the American Dream, 1790-1935. Chapel Hill, NC: University of North Carolina Press.

'Oriental Comedy'. 1931. Irish Press, 28 December.

'Review'. 1931. Irish Press, 28 December.

Roach-Higgins, Mary Ellen, and Joanne B. Eicher. 1995. 'Dress and Identity'. In Dress and Identity. Eds Mary Ellen Roach-Higgins, Joanne B. Eicher, and Kim K.P. Johnson. New York: Fairchild Publications.

Shukla, Pravina. 2015. Costume: Performing Identities Through Dress. Bloomington, IN: Indiana University Press.

Singleton, Brian. 2004. Oscar Asche, Orientalism and British Musical Comedy. Westport: Praeger.

Sisson, Elaine. 2011. 'Experimentalism and the Irish Stage: Theatre and Expressionism in the 1920s'. In Ireland, Design and Visual Culture: Negotiating Modernity, 1922-1992. Eds Linda King and Elaine Sisson. Cork: Cork University Press.

Teo, Hsu-Ming. 2012. Desert Passions: Orientalism and Romance Novels. Austin, TX: The University of Texas Press.

'The May Fete'. 1920. Irish Times, 14 May.

Open Access This chapter is licensed under the terms of the Creative Commons Attribution 4.0 International License (http://creativecommons.org/licenses/ by $/ 4.0 /)$, which permits use, sharing, adaptation, distribution and reproduction in any medium or format, as long as you give appropriate credit to the original author(s) and the source, provide a link to the Creative Commons license and indicate if changes were made.

The images or other third party material in this chapter are included in the chapter's Creative Commons license, unless indicated otherwise in a credit line to the material. If material is not included in the chapter's Creative Commons license and your intended use is not permitted by statutory regulation or exceeds the permitted use, you will need to obtain permission directly from the copyright holder.

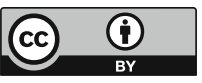

